\title{
Intraracial Diversity and Relations among African-Americans: Closeness among Black Students at a Predominantly White University ${ }^{1}$
}

\author{
Sandra S. Smith \\ University of Michigan \\ Mignon R. Moore \\ Columbia University
}

\begin{abstract}
A case study of black college students at a predominantly white liberal arts college is employed to question continuing assumptions in sociological research that blacks represent social, cultural, and economic homogeneity and that intraracial relations are close and without conflict. The article examines the extent to which black students feel close to other black students on campus, rely on one another for need satisfaction and social interaction, and share similar values, experiences, and attitudes. The authors find that the odds of closeness are significantly reduced for biracial students, for black students from low SES backgrounds, and for black students from predominantly white backgrounds. Among biracial students and those from predominantly white environments, social distance reflects their overall distance from the larger black community and is a function of their lack of "racial awareness." The social distance of low SES students appears specific to the community of black students within the college and is not expressed toward the larger black community. Moreover, feelings of distance appear to be driven by perceived social, cultural, and economic differences from other black students.
\end{abstract}

\section{INTRODUCTION}

Within sociology, the study of blacks is essentially the study of social and economic inequality. Such is the case within stratification research that

\footnotetext{
${ }^{1}$ This research was supported by a Spencer Foundation Mentor Research Grant and a grant from the Ford Foundation to the Program on Poverty and Social Welfare Policy at the University of Michigan. The authors would like to thank the following people for their critical feedback on this work: Edgar Epps, Alford Young, Jr., Carla

(C) 2000 by The University of Chicago. All rights reserved. 0002-9602/2000/10601-0001\$02.50
} 
American Journal of Sociology

examines blacks' disadvantaged positions in the labor market and poorer educational outcomes relative to whites, and such is the case within studies of race and ethnic relations, which focus almost exclusively on interracial conflict and the effects of racism and discrimination on targeted groups, to the neglect of intraracial group processes. Within these disparate areas of study, researchers presume that blacks hold similar values, attitudes, and experiences, share a collective perception of themselves as a social unit, have a qualitatively different culture and dissimilar life experiences compared to whites, and are dependent on each other for need satisfaction and social interaction, particularly to stave off feelings of racial alienation, isolation, and oppression. In sum, much of sociological research assumes that, as a group, blacks represent cultural, social, and economic homogeneity and that intraracial relations are close and without conflict. In so doing, what both of these areas of research has done is to provide a unidimensional picture of blacks, one in which they are aggregated and the nature of their intraracial relations and diversity obscured.

While there may have been less cause to question assumptions of closeness and homogeneity before the Civil Rights movement, when fewer cultural and socioeconomic distinctions could be made (Wilson 1978; Jaynes and Williams 1989; Farley 1996), one can question the extent to which these assumptions hold today given shifts in the demography of black America. Three trends are noteworthy. First, the growth of the black middle and upper-middle classes has resulted in an increased bifurcation of blacks by class status (Wilson 1978; Smith and Welch 1989; Jaynes and Williams 1989). Second, consistent with the first trend described above, the proportion of black Americans who have had interracial contact prior to adulthood has grown due to the increase in the number living in and attending racially integrated or predominantly white neighborhoods and schools (Massey and Denton 1988; Farley and Frey 1994; Frey and Farley 1996; Sigelman et al. 1996). Third, the population of foreignborn blacks has grown, as have populations of biracial and multiracial people with African ancestry (Farley and Allen 1987; Kasinitz 1992; Root 1992, 1996b; Outtz 1994; U.S. Bureau of the Census 1996; Waters 1996). ${ }^{2}$

O'Connor, Jennifer Barber, Pamela Bennett, David Harris, the Social Psychology Brownbag at the University of Michigan, as well as the $A J S$ reviewers. Please direct all correspondence to Sandra S. Smith at the Poverty Research and Training Center, 540 East Liberty, Suite 202, Ann Arbor, Michigan 48104.

${ }^{2}$ Before 1970, only 200,000 foreign-born blacks resided in the United States. Due in large part to the Hart-Cellar Immigration Reform Act of 1965, the number of foreignborn blacks had swelled to more than 1.9 million by 1996, representing over $6 \%$ of the black population in the United States, $10 \%$ of the black population in the Northeast, and approximately $25 \%$ of the black population in New York City, their primary city of relocation (Kasinitz 1992; U.S. Bureau of the Census 1996; Waters 1996). In 1970, three years after the Supreme Court declared unconstitutional laws prohibiting inter- 


\section{Intraracial Diversity}

Each of these demographic changes have increasingly diversified black America, making assumptions of closeness and homogeneity outdated and inaccurate.

In this article, we explore continuing assumptions about intraracial relations and diversity by examining feelings of closeness and distance, employing as a case study a population of black college students in attendance at a single, predominantly white university (referred to in this study as "Big City University"). First, we investigate the extent to which black students share values, attitudes, and experiences and rely on each other for need satisfaction and social interaction. Second, we conduct logistic regression analyses to predict closeness to other black students as a function of socioeconomic status, preadult integrative experiences, and racial and ethnic identification, factors that have contributed to growing black social, cultural, and economic diversity. Third, we draw from indepth interviews to provide context and insight into the relationships we uncover.

The most sociologically significant aspect of this work lies in its examination of the effect of intraracial diversity on relations in a context in which the saliency and meaning of race is particularly heightened. Given few instances in which people from dissimilar racial, ethnic, class, and cultural backgrounds converge and interact as peers for an extended period of time, the university setting offers one of the best opportunities to study how blacks from diverse backgrounds define their similarities and differences, the meanings they apply to these similarities and differences, the way diversity affects their feelings of closeness to or distance from other blacks, and the extent to which their closeness or distance is reflective of their feelings about the larger black community. For those accustomed to predominantly black surroundings and sensitive to issues of race, attending a predominantly white college may further signify their difference from the white majority and may help them define who they are as black individuals. For those raised in predominantly white environments, accustomed to being one of only a few blacks and generally unaccustomed to defining their existence primarily in terms of race, expectations from other blacks in terms of values, attitudes, style of dress, speech, and so on, may make race a more salient feature of their existence

racial marriages, black-white marriages totaled 65,000, and 12,556 babies were born to black-white couples. By 1991, the number of black-white intermarriages had grown to 231,000, and 52,232 black-white babies were born, an increase of more than $400 \%$ (Outtz 1994). Current estimates of black-white biracials are thought to be anywhere from 500,000 to 5 million persons, although many suspect that even these figures underestimate the true population of mixed-race people (Root 1992). To put these figures in perspective, between 1970 and 1992, the total number of interracial marriages increased from 310,000 to $1,161,000$, or $1.3 \%-2.2 \%$ of all marriages (U.S. Bureau of the Census 1993). 


\section{American Journal of Sociology}

whether they like it or not. Thus, although the fairly specific context of our study limits the extent to which we can generalize our findings to the larger community of blacks, we believe that this article represents an important first step at understanding intraracial group processes among a diverse population of African-Americans.

\section{THEORETICAL CONSIDERATIONS}

Homophily principles assert that individuals are drawn to those with similar attributes (Laumann 1973); therefore, we contend that what drives individuals' feelings of closeness to a particular reference group is the extent to which they perceive themselves to be similar to or different from the group in question. In this context, "perceptions of difference" and "feelings of closeness" represent two distinct concepts. "Perceptions of difference" denotes individuals' assessments of consistency between their social, cultural, and economic orientations and life experiences and those of the reference group. Specifically, individuals determine the extent to which the social norms, values, and attitudes that are important to them are compatible with those of the reference group, and judge whether or not their physical characteristics, style of dress, speech patterns, and general mannerisms resemble members of the group in question. Unlike "perceptions of difference," which indicates an assessment of commonalties with those in the reference group, "feelings of closeness" signifies the extent and nature of relations between individuals and the group in question. ${ }^{3}$ As such, it draws from the network conceptualization of closeness, which stresses tie strength and intimacy, and captures the extent of familiarity, intensity, and connectedness with individuals in the reference group or the group as a whole (Marsden and Campbell 1984).

Therefore, our theoretical framework models feelings of closeness to other blacks as a function of socioeconomic status, preadult integrative experiences, and racial/ethnic identification, with perceptions of difference playing a mediating role. In other words, increasing diversity among blacks resulting from class bifurcation, racial integration, and differential racial and ethnic identification will affect the extent to which they believe they share social, cultural, and economic orientations and experiences and will influence the extent and nature of their relations with individual blacks and the larger black community. In the remainder of this section,

\footnotetext{
${ }^{3}$ We would like to note that previous reviewers and the $A J S$ editorial board pointed out that these concepts- "feelings of closeness" and "perceptions of difference"-may actually be measures of the same underlying process of racial experience and identity. However, we continue to find the distinction between these concepts both valid and meaningful, but we encourage further examination of this question.
} 


\section{Intraracial Diversity}

we draw on disparate literatures that link feelings of closeness to socioeconomic status, preadult integrative experiences, and racial/ethnic identification, identifying as the common thread in each the mediating effect of perceptions of difference.

\section{Socioeconomic Background}

Several studies have examined the effect of socioeconomic status (SES) on blacks' feelings of closeness to other blacks and have generally found that individuals with higher SES report greater social distance from blacks as a group (Broman, Neighbors, and Jackson 1988; Demo and Hughes 1991; Thornton et al. 1997). Social distance is hypothesized to exist among those of higher SES because of their greater integration within mainstream America (Allen et al. 1989), their individual versus collective orientation toward success (Hall and Allen 1989), and their reduced sense of collective fate resulting because their class status insulates them from many problems faced by more disadvantaged blacks (Simpson 1998).

This may not be the case, however. We propose that when assessing closeness, low to middle SES blacks tend to view themselves as socioeconomically similar to the majority of other blacks, whom they see as predominantly from low to middle socioeconomic backgrounds. In contrast, middle- to upper-middle-class blacks view themselves as socioeconomically dissimilar to the majority of other blacks, whom they also see as predominantly from low to middle socioeconomic backgrounds. It is this perception of difference that is mediating the relationship between class status and feelings of closeness; the higher their SES, the greater their perception of differentness and feelings of social distance from other blacks. As a result, low to middle SES blacks report higher levels of closeness to other blacks relative to their more advantaged counterparts.

If we assume that the perception of differentness or sameness is driving the relationship between class status and feelings of closeness, we may not expect this same relationship to be found among black college students as has been found among a nationally representative sample of blacks. The socioeconomic background of black college students, especially those attending private colleges, is higher on average than the SES of the larger black community. ${ }^{4}$ If the comparison group for black students is the black

\footnotetext{
${ }^{4}$ Studies indicate that the socioeconomic backgrounds of black students attending predominantly white colleges and universities have become increasingly middle and upper-middle class. Hall and Allen (1989), e.g., find that a significant percentage of black students attending college at the University of Michigan, Ann Arbor, and the University of North Carolina, Chapel Hill, in 1986 were raised in middle- and uppermiddle-class families: $41 \%$ had family incomes of $\$ 25,000$ or more (in 1982 dollars), and $38 \%$ had parents with high-prestige professional occupations.
} 


\section{American Journal of Sociology}

student population rather than the general black population, low SES black students may perceive themselves as being significantly different from other, more advantaged students and thus may be more likely to report feelings of social distance. Middle- and upper-middle-class black students may view themselves as being fairly similar to other blacks on campus and thus may report greater feelings of closeness. We therefore hypothesize that feelings of closeness to other blacks is in part contingent on one's SES, the SES of their black reference group, and the extent to which they perceive this status as different from their own.

\section{Preadult Integrative Experiences}

Previous research has also identified integrative experiences with whites as an important factor in explaining blacks' feelings of closeness: preadult interracial contact has a negative effect on closeness to other blacks (Tatum 1987; Thornton et al. 1990; Demo and Hughes 1991; Harris 1995). Some researchers suggest that when black families move out of predominantly black environments, increased interactions with whites and other nonblacks contributes to greater social distance from blacks as a group (Demo and Hughes 1991). An alternative hypothesis contends that movement into predominantly white environments decreases time spent interacting with social groups and organizations within the black community, and it is this decline in interaction with other blacks that leads to greater social distance from blacks (Tatum 1987; Harris 1995).

Consistent with the latter hypothesis, Dawson (1994) argues that racial group identity depends a great deal on the extent to which individuals have access to information relevant to that identity and believe that a particular identity is consistent with their own reality. Racial identification becomes less salient to individuals when information about the political, economic, and social worlds of blacks is not accessible. This inaccessibility is more likely to occur when individuals do not reside in black communities, lack social networks to inform them of the happenings within black communities, or when they have become upwardly mobile, all of which may lessen the saliency of race in their lives (Dawson 1994, p. 11).

Drawing on the findings of previous research, we examine the effect of preadult integrative experiences on the odds of feeling close to other blacks, and we pay particular attention to whether closeness is more a function of the increased presence of whites in their social lives or the absence of interactions with blacks. As previous research suggests, we hypothesize that it is the absence of interactions with blacks, rather than the presence of whites, that is influential. We reason that because of the absence of interactions with other blacks, some having preadult integrative experiences will lack information about the political, economic, and 


\section{Intraracial Diversity}

social worlds of blacks, and consequently will be more likely to perceive little commonality between themselves and other blacks, resulting in feelings of distance.

Ethnic and Racial Identification

Ethnic identification.-Although researchers have yet to examine well the relationship between racial and ethnic identification and feelings of closeness among blacks, evidence exists suggesting that such intraracial diversity negatively influences intraracial relations. Consistent throughout many studies that have examined the process of assimilation and acculturation among foreign-born blacks is the finding that intraracial tensions and social distance pervade relations between communities of foreignborn and native-born blacks (Sutton and Makiesky-Barrow 1987; Woldemikael 1989; Kasinitz 1992; Waters 1996, 1999). The reasons for these tensions are not mutually exclusive. First, instead of attempting to fully integrate into the larger black community, many foreign-born blacks have instead distinguished themselves from native blacks by choosing to identify primarily in terms of ethnicity and nationality instead of race, and by maintaining the cultural norms of their homelands, such as style of dress and manner of speech. However, natives interpret these acts of ethnic display as ways to gain favor with whites. ${ }^{5}$

Second, native-born blacks are said to resent the foreign-born for hindering their opportunities for economic advancement. The foreign-born are accused of taking jobs that would otherwise go to natives or of taking jobs that natives shun because of low wages (Woldemikael 1989; Waters 1996, 1999). Moreover, given the many social and economic obstacles native-born blacks have to overcome in order to obtain their piece of the American pie, they are often confused and frustrated by the ability of the foreign-born to buy homes soon after immigrating (Woldemikael 1989). Feelings of antagonism between these two groups have resulted in "mutual stereotyping." The foreign-born brand native-born blacks as lazy and lacking commitment to education, upward mobility, and family; they also perceive native-born blacks as being overly sensitive to issues surrounding race. Meanwhile, natives criticize the foreign-born for what they perceive

${ }^{5}$ Indeed, research has shown that the foreign-born perceive better treatment from whites when their nonnative status is revealed. Whites generally compliment them on their accents, and white employers tend to prefer employees from the ranks of the foreign- rather than the native-born (Woldemikael 1989; Waters 1996, 1999; Newman 1999). 


\section{American Journal of Sociology}

as their arrogance and ignorance of the race and class issues that divide this country (Waters 1996, 1999). ${ }^{6}$

Thus, work in this area establishes that, although race is an important identifying group marker, there are other components of individuals' identities that may more strongly determine with whom they feel bonds. That some foreign-born blacks may choose their ethnic identification over their racial identification indicates that they may perceive themselves differently from other blacks. They may eat different foods, speak with foreign accents, listen to different music, and dress and act differently. In addition, they may have values, attitudes, interests, and issues that identify them as a group distinct from the native-born black community. Their decision to identify ethnically suggests that they perceive themselves differently from their nonethnic-identified counterparts and signals their social distance from blacks as a racial group.

Racial identification.-Although relatively sparse and concentrated in the fields of social work and psychology, the social science literature on biracial persons consistently identifies two areas of conflict that may have consequences for feelings of closeness: racial identity and social marginality (Brown 1990; Overmier 1990; Gibbs 1998). While the process of racial identification may not be difficult for monoracial individuals, it can be challenging for biracials. Although born with dual or multiple racial and cultural identities, children of different-race parents are often expected to identify with one race, usually that of the minority parent. In the United States, children of black-white interracial unions have historically been defined as black, a practice that has been strongly supported by both black and white communities, laypersons and clinicians alike. However, as the trend toward biracial identification grows, so too does intraracial tension among blacks, as some within the black community ostracize self-identified biracials whom they perceive as downplaying their blackness in favor of their whiteness to gain special treatment from whites (Sebring 1985; Bowles 1993; Daniel 1996). ${ }^{7}$

\footnotetext{
${ }^{6}$ Recent work of race and ethnicity scholars suggests that, to some extent, intraracial tensions decline with the second generation of black immigrants, primarily because the offspring of the foreign-born are more likely to identify with American blacks than are their parents (Waters 1996).

${ }^{7}$ A trend appears to be developing in which biracials are choosing to identify with all aspects of their racial backgrounds rather than accepting traditional U.S. societal attitudes in which everyone with African ancestry is viewed solely as black (Daniel 1996; Thornton 1996; Spencer 1997). No longer willing to choose between their multiple racial and cultural heritages, and no longer willing to accept their social marginality, since 1990, mixed-race individuals have organized a movement to legitimate their status as a distinct racial group (Njeri 1988; Mathews 1996; Spencer 1997). As evidence of the trend toward increased multiracial identification, whereas in 1970, 720,000 people in the U.S. census described themselves outside of the four major racial classifications,
} 


\section{Intraracial Diversity}

Intimately tied to the issue of racial identity is social marginality. Researchers and clinicians have found that biracial individuals often have a difficult time answering the question, Where do I fit? (Sebring 1985; Overmier 1990; Brown 1990; Gibbs 1998). Rejected by both majority and minority peers because of their "exotic" features, biracial adolescents can experience difficulty identifying peers who accept and validate their racial and cultural uniqueness (Overmier 1990). The extent to which biracials are accepted depends on the extent to which their physical characteristics, style of dress, speech patterns, and general mannerisms match those in the black community, as well as the extent to which biracials accept a black racial identity and show commitment to the mores of the black community (Sebring 1985). The odds of social acceptance are high for black biracials who are easily identified as black given certain physical features, cultural style, and commitment to the black community, but the odds of acceptance are low for biracials who are racially and culturally difficult to categorize (Brown 1990).

\section{Summary}

In sum, although disparate in nature, the literature on SES, preadult integrative experiences, and racial and ethnic identification suggests that homogeneity among blacks should not be assumed and that intraracial relations generally, and feelings of closeness specifically, may be influenced by the extent to which individuals perceive commonalties between themselves and other blacks in terms of their social, cultural, and economic orientations and experiences. We explore these possibilities by addressing the following questions: To what extent do blacks (1) feel close to or distant from other blacks, (2) rely on each other for need satisfaction and social interaction, and (3) share similar values, attitudes, and experiences?

\section{DATA AND METHODS}

\section{Data Collection and Sample Characteristics}

To determine the extent to which an intraracially diverse population of blacks share similar values, attitudes, and experiences, rely on each other for need satisfaction and social interaction, and feel close to or distant from other blacks, we needed a socially, culturally, and economically heterogeneous population on which to test our hypotheses. Given the few settings in which people from dissimilar backgrounds converge and interact as peers for an extended period of time, we identified the college

by 1990, 10 million people were identified as "other," although it cannot be determined the proportion who are of mixed-race heritage (Spencer 1997). 


\section{American Journal of Sociology}

campus as the setting to address our research concerns. Thus, we surveyed all of the black undergraduate students at a private, predominantly white university. Mail-in questionnaires consisting of closed-ended questions were distributed to all 134 black undergraduates at Big City University, where they constituted approximately $3 \%$ of the total undergraduate population. While some of the survey questions were original constructions, others were derived from the National Study of Black College Students at the University of Michigan (Allen 1992). The initial response rate of $65 \%$ was increased through phone surveys, providing a final response rate of $76 \%(N=102)$.

In addition, we collected in-depth interviews with a smaller sample of respondents who completed the mail-in survey. This subsample was chosen to represent the opinions of distinct groups of respondents in the general survey. We stratified survey participants into four groups in order to obtain a variety of perspectives and experiences from the black student body. This decision was made after preliminary analysis of the data indicated that closeness to other black students was significantly correlated with race and ethnic identification and racial composition of friendship networks on campus. The four groups are as follows:

1. Those who reported their racial/cultural identification as biracial, multiracial, foreign-born, or who reported themselves as members of an ethnic group, regardless of racial composition of friendship group.

2. Those who responded that all or most of their friends were black.

3. Those who responded that half or some of their friends were black.

4. Those who responded that few or none of their friends on campus were black.

We randomly contacted students from each of these four groups by telephone and invited them to participate in the open-ended interview. Thirty students were interviewed about topics relating to their experiences prior to attending college, their experiences with black students since enrolling in college, and how they currently perceived themselves relative to other blacks on campus. ${ }^{8}$

Variables

Dependent variable.-In past studies, "closeness" has been used as a measure of black identity, theoretically capturing the extent to which blacks consider themselves a part of the collective. To operationalize this concept of closeness, researchers generally employed a series of questions asking blacks how close they felt in their ideas and feelings to blacks who are

${ }^{8}$ Both interviewers were African-American. 
(1) poor, (2) religious, (3) young, (4) middle class, (5) working class, (6) older, (7) elected officials, and (8) professionals, with responses ranging from not at all to very close. These measures were then summed and used to reflect blacks' identification with all blacks. However, such a construction, while capturing affective response to all blacks, does not take into consideration context, nor does it account for how closeness relates to day-to-day experiences. In sum, this conceptualization fails to capture the extent and quality of relations within a community of blacks, and therefore significantly limits the empirical ability to link intraracial diversity to feelings of closeness. Consequently, a measure indicating one's identification to all blacks would be inappropriate in this context.

Instead, we draw from network conceptualizations of closeness that emphasize tie strength and intimacy, and we created a measure based on four dimensions of closeness: closeness to individual black students; closeness to the black community on campus; the extent of intimate association with other black students; and quality of experiences with other black students. Questions asked to arrive at these dimensions include the following:

How alienated or isolated do you feel from other black students?

$(1=$ extremely; $5=$ not at all $)$

How would you describe your relations at this university with black students?

$(1=$ no contact; $5=$ excellent $)$

What proportion of your friends on campus are black?

$(1=$ none; 5 = all $)$

To what extent do you feel part of the black community on campus?

$(1=$ not at all; $5=$ totally)

Each of these dimensions represents a scale that was then summed for each respondent to create one measure (minimum score $=4$, maximum $=20$; Cronbach's $\alpha=.81$ ). Higher scores indicate stronger feelings of closeness. Respondents were then categorized into three categories of closeness: socially distant, close, and very close. Taking the mean closeness score across all respondents, we categorized those who scored lower than one standard deviation below the mean as socially distant from other black students and those scoring more than one standard deviation above the mean as very close to other black students. Those scoring within one standard deviation of the mean were categorized as close.

Covariates.-It is our contention that closeness to other black students is significantly related to the extent of social interaction with other black students, as well as having similar values, attitudes, and experiences as other black students. To examine these relationships, we operationalized social interaction using several variables that measure the frequency of participation with black students in formal and informal activities and 


\section{American Journal of Sociology}

the extent of participation in minority-oriented activities, black-specified activities, general campus activities, and off-campus activities. Frequency of participation in formal and informal activities was determined by asking how often the respondent does the following activities with other black students: eats meals, watches TV/movies, attends cultural activities or parties, hangs out/plays games, and participates in study groups or group projects. Frequency of participation for each activity was measured from 1 (never) to 5 (frequently). Responses were summed and averaged across the eight items (Cronbach's $\alpha=.89$ ).

To determine the number of minority-oriented activities, respondents were told to indicate whether they have ever been involved in any of the following activities: black student union or association; black cultural center; black studies program/center; tutorial work (as a tutor); tutorial help or other academic support (as a tutee); mentoring program (with faculty or administrators); peer support program; summer program (e.g., Upward Bound, pre-engineering, etc.); special black cultural/educational events on campus; other black or minority programs on this campus. The number of yes responses to 10 activities was summed. A second variable, number of black-specified student activities, measures participation in only those five activities specific to black students.

Because it could be argued that socially distant black students participate less in minority-oriented and black-specified activities because they are alienated from the general campus community and therefore less likely to participate in all campus activities, we also examined participation in general campus activities and off-campus activities. Participation in general campus activities was determined by responses to how often the respondent took part in each of the following activities since enrolling in college: intramural athletics; intercollegiate athletics; hanging out or playing games; meetings or other activities of a club, organization, or student government group; studying with other students; attending interracial parties; cultural activities; residence hall activities; on-campus religious organizations. For each, any participation was coded as "1," otherwise " 0 ," and summed to create one measure of participation in general campus activities. The number of involvements in off-campus activities was measured by responses to how often the respondent attended a party or social event away from campus, participated in off-campus social activities with friends who do not attend the university, and relied on off-campus activities or organizations for recreational or social enjoyment. Any participation in each was coded "1" and summed to create one measure of offcampus involvements.

Attitudes.-To determine the extent to which black students have shared values and attitudes, we identified interracial relationships as an issue particularly sensitive for blacks as a group. Responses to the fol- 


\section{Intraracial Diversity}

lowing questions "How do you view other black students who hang out with nonblacks?" and "How do you view other black students who date nonblacks?" were recoded into approvingly, indifferent, and disapprovingly from a Likert-type five-point scale. Those who report that they disapprove of interracial friendships or dating are compared to those who report indifference or approval. Respondents were also asked "How frequently do you date nonblacks?" Responses ranged from 1 (frequently) to 4 (never). Those who report never having dated interracially are compared to those who have occasionally to frequently dated interracially.

Background experiences.-Previous research suggests that feelings of closeness to one's racial group are negatively associated with SES and positively associated with having a predominantly black racial identification (Broman et al. 1988; Allen et al. 1989; Harris 1995). Our indicator of SES encompasses both measures of family income and parental education and was created based on the measure used by Bowen and Bok (1998). Black students categorized as having low SES were those for whom no parents had attained a college degree (B.A. or equivalent) or higher and for whom family income was less than $\$ 25,000$. Black students coded as having high SES were those who had at least one parent who had a college degree or higher, and for whom family income was $\$ 75,000$ or more. All others fell into the middle SES category.

To determine preadult integrative experiences, we asked about the racial proportion of respondents' neighborhoods and high schools and how many of their good friends during high school were black, white, Hispanic, or Asian. For multivariate analyses, however, we created two racial composition scales, one measuring the proportion of blacks in respondents' neighborhoods, high schools, and friendship groups during high school, and the second measuring the proportion of whites in these areas of their lives. The scales range from 1 to 6 (no blacks/all blacks, no whites/all whites) (Cronbach's $\alpha=.79$ and .80 , respectively).

Finally, we include a variable not previously discussed in similar research: racial and ethnic identification. To determine how respondents self-identified, we asked "What is your cultural identification?" Respondents were asked to choose one of the following: (1) black/African-American or (2) black/other. Those reporting "black/other" were asked to specify their identity. Because the survey was self-administered, respondents' selfclassifications were their own constructions. However, based on the responses they gave, we identified three categories: monoracial, bi- or multiracial, and ethnic identified. We identified as monoracial those who chose the black/African-American categorization and reclassified those indicating black/other into biracial and ethnic identified. ${ }^{9}$ The ethnic identified

\footnotetext{
${ }^{9}$ Monoracials are those who claim a single racial heritage, and biracials are those
} 


\section{American Journal of Sociology}

consisted of those who identified in terms of nationality, language, and/ or religion. Examples from the data include "Jamaican," "German/American," "Canadian-African," "Haitian," and "African." Those who reported having two or more racial identities were classified as biracials. For example, some students described themselves as "biracial," "mulatto," or "half-black/half-white." In the case of three respondents, reclassification could go in either direction as their self-identification indicated a biracial and an ethnic-identified status. ${ }^{10}$ In such cases we determined that if the respondent was a product of parents from two different ethnic and racial groups, the biracial classification would take precedence over the ethnic categorization. ${ }^{11}$

\section{Methods}

To determine mean differences by closeness in frequency of participation, the number of activities in which students participate, and attitudes toward interracial relationships, we employ analyses of variance. Because we assume that the relationship between college experiences, attitudes, and closeness can go in either direction-black students infrequently participate in activities with other black students because they are socially distant or they are socially distant because they infrequently participate in activities with other black students-we do not use these measures as predictors of closeness in our multivariate analyses. Indeed, one can argue that these are measures of closeness as well. To predict closeness to other black students, we employ logistic regression to examine the effect of racial and ethnic identification, socioeconomic status, and preadult integrative experiences, controlling for gender and year in school. Finally, in-depth interviews are used as an analytic tool providing context and insight into the relationships uncovered.

whose parents are of two different socially designated racial groups (Root 1996b, pp. ix-xi).

${ }^{10}$ This was the case for one student who self-identified as black and Puerto Rican, another who identified herself as black and Jewish, and another who described herself as Creole.

${ }^{11}$ In deciding that being biracial would take precedence over ethnicity, we encountered the problem of determining the classification for the student who self-categorized as black and Puerto Rican. Because a substantial percentage of Puerto Ricans also classify themselves as black (Denton and Massey 1989), it is unclear which classification she should have. As a result, we conducted our analyses both ways and found that the results did not differ substantively or statistically. Thus, we present the findings in which the student is classified as a biracial. 
Intraracial Diversity

TABLE 1

Means and SDs of Variables in the Analyses

\begin{tabular}{|c|c|c|c|}
\hline & Mean & $\mathrm{SD}$ & Range \\
\hline \multicolumn{4}{|l|}{ Dependent variable: } \\
\hline Mean closeness score & 13.60 & 3.51 & $4-20$ \\
\hline \multicolumn{4}{|l|}{ Categories of closeness: } \\
\hline Socially distant $\ldots \ldots \ldots \ldots \ldots \ldots \ldots \ldots \ldots \ldots$ & .21 & & $0-1$ \\
\hline Close $\ldots . . . \ldots \ldots \ldots$ & .58 & & $0-1$ \\
\hline Very close...$\ldots \ldots$ & .21 & & $0-1$ \\
\hline \multicolumn{4}{|l|}{ Ethnic background: } \\
\hline Monoracial ........ & .72 & & $0-1$ \\
\hline Biracial $\ldots . . . \ldots . .$. & .15 & & $0-1$ \\
\hline Ethnic identified & .13 & & $0-1$ \\
\hline \multicolumn{4}{|l|}{ SES: } \\
\hline Low & .14 & & $0-1$ \\
\hline Middle $\ldots \ldots \ldots \ldots$ & .60 & & $0-1$ \\
\hline High $\ldots \ldots \ldots . . . .$. & .26 & & $0-1$ \\
\hline \multicolumn{4}{|l|}{ Preadult integrative experiences: } \\
\hline Black racial composition scale ........... & 3.72 & & $1-6$ \\
\hline White racial composition scale $\ldots \ldots \ldots \ldots$ & 3.37 & & $1-6$ \\
\hline \multicolumn{4}{|l|}{ College experiences: } \\
\hline Frequency of participation scale ......... & 2.95 & .11 & $1-6$ \\
\hline$N$ of minority-oriented activities $\ldots . \ldots \ldots$ & 3.00 & 2.08 & $0-10$ \\
\hline$N$ of black-specified activities $\ldots \ldots \ldots \ldots$ & 1.67 & 1.17 & $0-5$ \\
\hline$N$ of general campus activities $\ldots \ldots \ldots \ldots$ & 5.93 & 1.79 & 0-9 \\
\hline$N$ of off-campus activities $\ldots \ldots \ldots \ldots \ldots$ & 2.37 & .96 & $0-3$ \\
\hline \multicolumn{4}{|l|}{ Attitudes: } \\
\hline Disapproves of interracial friendships ... & .09 & & $0-1$ \\
\hline Disapproves of interracial dating $\ldots \ldots \ldots$ & .19 & & $0-1$ \\
\hline Ever dated interracially $\ldots \ldots \ldots \ldots \ldots \ldots$ & .51 & & $0-1$ \\
\hline \multicolumn{4}{|l|}{ Controls: } \\
\hline \multicolumn{4}{|l|}{ Gender: } \\
\hline Male . & .37 & & $0-1$ \\
\hline Female & .63 & & $0-1$ \\
\hline \multicolumn{4}{|l|}{ Class level: } \\
\hline Freshman .... & .23 & & $0-1$ \\
\hline Sophomore $\ldots \ldots \ldots \ldots \ldots \ldots \ldots \ldots \ldots$ & .23 & & $0-1$ \\
\hline 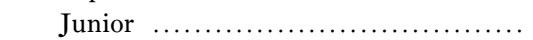 & .31 & & $0-1$ \\
\hline Senior $\ldots \ldots \ldots \ldots \ldots \ldots \ldots \ldots \ldots \ldots \ldots \ldots \ldots$ & .23 & & $0-1$ \\
\hline
\end{tabular}

\section{RESULTS}

\section{Descriptive Statistics}

Descriptive statistics are displayed in table $1 .^{12}$ The mean of the closeness measure, 13.6, was used to distinguish between socially distant students,

${ }^{12}$ The sample population of black undergraduates in this study mirror very closely that of the black undergraduate population at Big City University in terms of gender 
American Journal of Sociology

close-feeling students, and very-close feeling black students. Based on this conceptualization of closeness, $21 \%$ of the sample were socially distant, $58 \%$ were close, and $21 \%$ were very close to black students on campus.

Responses to our survey indicate that black students at this predominantly white university are diverse in their racial and ethnic identification, socioeconomic backgrounds, and preadult integrative experiences. As shown in table 1 , approximately $15 \%$ of respondents reported that they are biracial and almost $13 \%$ are ethnic identified. Combined, these two groups represent more than one-quarter of all respondents. While the majority of black students were from middle-class backgrounds, approximately $27 \%$ and $14 \%$ reported high and low SES backgrounds, respectively. More than half of the students reported growing up in racially integrated or predominantly nonblack neighborhoods, attending racially integrated or predominantly nonblack high schools, and having friendship networks during high school that were racially integrated or predominantly nonblack. The mean score for the racial composition scale indicating the proportion of blacks in respondents' social environments prior to college is 3.72; that for whites is 3.37 . These scores suggest that the average student was raised in an environment in which about half of the high school students, neighbors, and good friends during their preadult experiences were black and half were white.

In terms of college experiences, on average, black students participate in three minority-oriented activities, 1.5 black-specified activities, six general campus activities, and approximately two off-campus activities. Moreover, the mean frequency of participation in informal activities with other black students indicates that, on average, black students occasionally participate in informal activities with other black students. Finally, while $9 \%$ of black students reported that they disapproved of interracial friendships, $19 \%$ reported disapproval of interracial dating, and $51 \%$ reported having dated interracially.

\section{College Experiences}

Table 2 shows the association between the level of participation in extracurricular activities and the level of closeness respondents feel toward blacks on campus. Socially distant black students participate in fewer informal activities with other black students and take part in significantly fewer minority-oriented and black-specified student activities compared to close-feeling students. While the socially distant reported involvement

and classification status. Female students made up $63 \%$ of the black undergraduate population, which further breaks down by enrollment status: $25 \%$ freshmen, $25 \%$ sophomores, $28 \%$ juniors, and $22 \%$ seniors. 
Intraracial Diversity

TABLE 2

One-Way Analyses of Variance Correlating Closeness to Black Students

\begin{tabular}{|c|c|c|c|}
\hline & Socially Distant & Close & Very Close \\
\hline \multicolumn{4}{|l|}{ College experiences: } \\
\hline $\begin{array}{l}\text { Frequency of participation in (in)formal } \\
\text { activities with other black students } \ldots\end{array}$ & $1.72^{* \dagger}$ & $3.01^{\dagger}$ & 3.92 \\
\hline Minority-oriented activities $\ldots . \ldots \ldots \ldots . . .$. & $1.19^{* \dagger}$ & $3.07^{\dagger}$ & 4.55 \\
\hline Black-specified activities $\ldots \ldots \ldots \ldots \ldots$ & $.52^{* \dagger}$ & $1.75^{\dagger}$ & 2.55 \\
\hline General campus activities ............... & 5.67 & 5.73 & 6.73 \\
\hline Off-campus activities $\ldots \ldots \ldots \ldots \ldots \ldots \ldots$ & 2.29 & 2.34 & 2.55 \\
\hline \multicolumn{4}{|l|}{ Attitudes about interracial interactions: } \\
\hline Disapprove of friendships ............... & $.00^{\dagger}$ & $.07^{\dagger}$ & .27 \\
\hline Disapprove of dating $\ldots \ldots \ldots \ldots \ldots \ldots$ & $.00^{\dagger}$ & .19 & .36 \\
\hline Ever dated interracially $\ldots \ldots \ldots \ldots \ldots$ & $.76^{\dagger}$ & .50 & .29 \\
\hline
\end{tabular}

* Significantly different from close group at $P<.05$

" Significantly different from very close group at $P<.05$.

in an average of 1.2 minority-oriented activities, respondents who felt close to blacks on campus participated in an average of three activities, and the very close reported involvement in about 4.5 of these activities. We found a similar pattern with respect to black-specified activities in that the socially distant took part in significantly fewer activities compared to the close and very close. Means tests of significance indicate that these differences are strong and significant.

Because it could be argued that socially distant black students participate less in minority-oriented and black-specified activities because they are alienated from the general campus community and therefore less likely to participate in all campus activities, we also examined participation in general campus and off-campus activities. Table 2 shows that participation in general and off-campus activities do not differ significantly by closeness. Overall, these results indicate that socially distant students participate in fewer minority-oriented and black-specified activities not because they are nonparticipants generally, but because they do not feel close to other black students specifically. In other words, although socially distant students consider themselves "outsiders" in reference to the black community on campus, they appear very much integrated into the general campus community. ${ }^{13}$

${ }^{13}$ To determine if patterns of participation varied by gender, we conducted means tests of gender differences in frequency and number of involvements. We found that with the exception of participation in general campus activities, no gender differences exist. Males had significantly more involvements in general campus activities (2.77 vs. 2.54; $P=.092)$, primarily because of greater involvements in intramural and intercollegiate athletics. However, neither gender group reported greater participation in minorityoriented or black-specified activities. We also sought to determine whether geographic 


\section{American Journal of Sociology}

Through in-depth interviews, we learned that frequency and extent of participation in two specific activities defined black students' connection to other black students and the black community on campus: frequency of dining at the Black Table, and the extent of participation in the events and meetings of the Black Students Organization. At Big City University there are three dining halls on campus. Within each dining hall a specified number of tables is assigned to each house (or dormitory floor) in the housing system. These assignments are primarily used during the first few weeks of each school year to promote house unity and a sense of community for students. Throughout the remainder of the school year, students are encouraged, but not required, to eat with their housemates. Because some black students see mealtime as a chance to connect and to interact with other black students whom they rarely see, they often sit at an unassigned table in the dining hall. Students refer to this table as "the Black Table," as it provides a public space in which black students can meet and feel comfortable in a social context.

The Black Students Organization (BSO) functions similarly. As Cornell, ${ }^{14}$ a third-year student who is close to other black students explains

From BSO, I think I gain some awareness, and at times support, [although] not as much support as we'd like. I gain awareness at least about what the general black community is trying to do or is trying to organize around. So in that way it's some type of medium where we can meet and at least have a general idea of what's going on on campus. In that sense it's good,

distribution was correlated with closeness and college experiences. Specifically, we conducted means tests measuring whether students raised in "Big City" or the larger metropolitan area outside the city were less likely to participate in minority-oriented and black-specified activities and feel close to other black students because of friends and relatives in the local area they could rely on for social support and engagement. We found that although students from Big City and the Big City metropolitan area reported more involvements in off-campus activities than those from outside the Big City area, they also reported a greater frequency of participation in activities with other black students and a greater number of involvements in minority-oriented and black-specified activities on campus. Moreover, compared to students from the metropolitan area and beyond, a higher proportion of those from Big City were categorized as feeling "close" or "very close" to other black students and the black community on campus. Ninety percent of students from Big City were so categorized relative to $71 \%$ of those from the metropolitan area and $78 \%$ of those from outside Big City or the metropolitan area. Although these differences were found to be statistically insignificant, they indicate that students from Big City were relying on both relatives and friends off-campus as well as the community of black students at Big City University for social, psychological, and emotional support and engagement. Their local ties did not appear to negatively influence the extent and nature of their relations with other black students and the black community on campus.

${ }^{14}$ Respondent names and identifying markers have been changed to protect their identities. 
like for networking or information. I think that that's probably the biggest thing I get out of it now.

The Black Table and the BSO represent two places where black students at Big City University interact in their own social groups to buffer the potentially isolating and alienating larger campus environment and to maintain a connection to other black students.

The choice that an individual makes to sit at the Black Table or to participate in BSO functions is a major indicator of how his or her connection and commitment to the black community on campus is assessed by others. The majority of students interviewed reported that frequent attendance at the Black Table and participation in BSO functions are indicative of closeness to other black students and integration into the black community on campus. The extent of individual participation in these activities is positively associated with how close black students feel to other black students. In data not shown, $15 \%$ of the socially distant reported eating meals with other black students with some frequency, while $69 \%$ of close students and $95 \%$ of very close students reported the same. Similarly, while only one-third of socially distant students reported ever having involvement with the BSO, three-quarters of close students, and almost all of the very close students reported involvement with the BSO. As one student declared, "If you don't interact with blacks at the dining hall or through the Black Students Organization, you're really not going to be part of the black community" (Cornell).

Upon entering school, most students made initial attempts to interact with other black students and become integrated into the black campus community, primarily by attending BSO meetings or sitting at the Black Table. ${ }^{15}$ However, after these initial interactions, socially distant students reported they had little in common with other black students, finding that the issues that seemed important to other black students were not important to them. Melanie, a third-year student who scored below the mean on the social distance scale, explained her lack of participation in blackspecified activities in the following way:

I've tried. I tried. I went to BSO a few times, and it just wasn't right for me. They have some neat activities during black history month, some mov-

\footnotetext{
${ }^{15}$ In many cases, students who make initial attempts do so after being recruited or encouraged by BSO members. Each year, the administration of Big City University supplies the Black Students Organization with a list of students who are classified as black. As a part of the organization's mission, the BSO uses this list to send emails and other correspondences about BSO-sponsored activities, regardless of their official membership in the BSO because the organization considers all black students as members. Therefore, black students are made aware of BSO's activities from the time they enroll at the university.
} 


\section{American Journal of Sociology}

ies and stuff, but altogether I think it was just too different. Like, just because you're black doesn't mean you have something in common.

Another socially distant student, Rhonda, described one of her first experiences with black students. She recalls

I remember once when I was sitting at the table where the black students sit in one of the dining halls here, and they were talking, [saying] "You know when I first came here it was a culture shock, totally" or saying all of these things that I really couldn't relate to because I'm used to seeing five black people and 100 white people, and it's sort of like, perhaps it bothers me on some level, but I'm so accustomed to it that it doesn't create any insecurity in me. I don't feel like I need to just run to the closest black person and hold on to them. I found out how to be independent and feel like I can be self-sufficient, because if there's only five black people and you don't like any of them, and you're in school with 600 kids, you'd better learn how to depend on something! So when I came here I had the same kind of feeling, and it seems that actually that's always backfired on me because I think people sense it as me not wanting to be with them because, I don't know how to say this so it doesn't sound bad, but I don't need them. Do you know what I mean?

Rhonda made an initial attempt to connect with other black students by sitting with them at the Black Table. However, through her interactions with them she discovered that not only did her past experiences differ significantly from those of the other students at the table (she intimates a predominantly white background), her present orientation differs as well. Unlike many other black students, she is accustomed to and comfortable in predominantly white settings, did not experience culture shock upon enrolling in college, and does not know or has not known for some time what it means to feel alienated from the white majority. Rhonda perceives herself as being significantly different from her black peers and as a result feels social distance from them. She rarely relies on them for social interaction. Therefore, she rarely sits at the Black Table or attends functions sponsored by the BSO, even though she initially made attempts to do so.

\section{Attitudes toward Interracial Friendships and Dating}

Significant differences in attitudes were also found by levels of closeness. Findings listed in table 2 show that none of the socially distant black students disapproved of interracial friendships or interracial dating, but about $27 \%$ of students who felt very close to blacks on campus disapproved of friendships with nonblacks, and 36\% disapproved of interracial dating. Moreover, while three-fourths of socially distant blacks have ever 


\section{Intraracial Diversity}

dated outside of their race, half of close-feeling blacks and less than onethird of respondents who feel very close to blacks on campus have ever dated someone outside of their race. ${ }^{16}$

The stance one takes on interracial contact generally, and interracial dating specifically, has significant consequences for how individuals are perceived in the larger black community (Porterfield 1978; Spickard 1989; Rosenblatt, Karis, and Powell 1995). Interracial dating, and to a lesser extent, friendships with nonblacks, have generally been viewed negatively or suspiciously by some blacks (Porterfield 1978; Spickard 1989; Rosenblatt et al. 1995). On the extreme end, close and intimate interracial social relationships may be interpreted as a disavowal of African heritage (Collins 1990; Rosenblatt et al. 1995). Many view interracial relationships and marriage as the source of the breakdown of the black family and the black community (Porterfield 1978; Rosenblatt et al. 1995; St. Jean and Parker 1995). Consequently, those in favor of such relationships may be perceived as lacking loyalty, connection, and commitment to other blacks and to the black community. Explaining her disapproval of interracial dating, Crystal, a fourth-year student categorized as close to other black students exclaimed:

I mean, the breakdown of the black household, good educated black men are marrying white women, and what's going to happen to the educated [black] woman who wants to have this kind of family, to reproduce more children? It's easier to reproduce if you have two educated individuals in the household, that's a better household, a lot of people think. That is an issue. It's more than just "I'm pissed because you're dating this white woman." There are other issues behind that. There are reasons why black people feel that way.

Tamara expressed suspicion toward blacks who choose to interact on a social or personal level with nonblacks. She explained succinctly:

I guess to study with that person would be fine, but to date I think would cause a problem. Anything that's nonschool related I think would pose a problem.

Crystal suggests that interracial dating is a major issue for blacks as a whole. To her, it signals a betrayal by black men to black women, the black family, and to the propagation of the black race, and anyone who does not view this issue similarly and with equal vigor is offensive. As she later states, "If you started to have that point of view on things [positive view of interracial dating], then it's kind of like, well, you are

${ }^{16}$ We find no evidence of gender differences in attitudes toward interracial relationships in our data. 


\section{American Journal of Sociology}

offensive to me." For Crystal and Tamara, this issue provoked feelings of betrayal, loss, and anger.

Although only a minority of students surveyed indicated disapproval of such relationships, many of the interviews suggested that interracial dating and friendships were behaviors frequently discussed and sanctioned in the black community on campus. Keisha, a socially distant second-year student, explained the reaction she received from a fellow black student after she decided to pledge a predominantly white sorority. She recounted:

Last year when I was doing the whole pledging for the sorority, a pretty much all-white sorority, and one of the [black] guys came up to me and he's like, "I don't really think it's such a good idea for you to be hanging out with all these white girls," at which point I threw a hissy fit.

Another student, Melanie, who scored below the mean on the closeness scale, reported her experience with the black community's condemnation of interracial dating. She explained:

I thought [college] would just be like people would mix and that it wouldn't be a question of your race. Just like you should get along. And even I know, I have an acquaintance who's black, who has a white boyfriend, and she gets a lot of criticism about that from the black community.

Past research has assumed that blacks have similar attitudes about issues relevant to the black community. Employing attitudes about interracial relationships as an example of an issue relevant to the black community, our results suggest that important and not inconsequential differences do exist. Those who publicly disagreed with the prevailing sentiment that interracial dating is not in the best interests of the larger black community were often deemed to be misguided at best and traitorous and offensive at worst. Differences such as these helped to define the level of loyalty and commitment that each black student on campus felt for the other black students and for the larger black community and clearly established those who were close and those who were socially distant.

\section{Logistic Regression Results and Interpretation}

To predict whether a black student feels close to other black students, we recoded our dependent variable into a dichotomous variable $(1=$ close, very close; $0=$ socially distant) and regressed closeness on racial and ethnic identification, SES, and preadult integrative experiences, controlling for gender and students' classification status (i.e., whether they are 


\section{Intraracial Diversity}

TABLE 3

Odds Ratios from Logistic Regression Analyses Predicting Feelings of Closeness to Other Black Students

\begin{tabular}{|c|c|c|}
\hline & \multicolumn{2}{|c|}{ MODEL } \\
\hline & 1 & 2 \\
\hline \multicolumn{3}{|l|}{ Racial/ethnic identification: } \\
\hline Biracial & $.20^{* *}$ & $.20^{* * *}$ \\
\hline Ethnic identified .......... & .40 & .37 \\
\hline \multicolumn{3}{|l|}{ SES: } \\
\hline Middle...$\ldots \ldots \ldots \ldots$ & .34 & .36 \\
\hline Low $\ldots \ldots \ldots \ldots \ldots \ldots \ldots \ldots \ldots \ldots \ldots \ldots$ & $.12^{* *}$ & $.12^{* *}$ \\
\hline \multicolumn{3}{|l|}{ Preadult integrative experiences: } \\
\hline Black racial composition scale .......... & $1.56^{*}$ & \\
\hline White racial composition scale $\ldots . \ldots .$. & & .71 \\
\hline \multicolumn{3}{|l|}{ Controls: } \\
\hline Gender (female) & 1.06 & .99 \\
\hline Classification $\ldots \ldots \ldots \ldots \ldots \ldots \ldots \ldots \ldots$ & 1.05 & 1.04 \\
\hline Constant $. . . . . . . \ldots \ldots \ldots . . .$. & $1.08^{* *}$ & $3.99^{*}$ \\
\hline 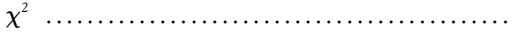 & 15.74 & 13.96 \\
\hline-2 log-likelihood (initial) & 98.72 & 99.18 \\
\hline$d f \ldots \ldots \ldots \ldots$ & 7 & 7 \\
\hline
\end{tabular}

first-, second-, third-, or fourth-year students). We also tested whether the social distance some experience is more a function of the absence of blacks in one's social environment prior to attending college or the presence of whites. Two models were specified. Model 1 tests for the importance of blacks in one's environment as a predictor of closeness to blacks in college. Model 2 tests for the presence of whites in preadult social groups as the more important experience relating to closeness toward blacks in school.

Results are displayed in table 3 . We find that compared to monoracial students, biracial students have $80 \%$ lower odds of feeling close to other black students $(P=.0138)$, and compared to high SES students, low SES students have $88 \%$ lower odds of feeling close to other black students $(P$ $=.0307)$. In addition, the odds of feeling close to other black students in college are significantly greater for those with more blacks in the preadult social environment. For every one-point increase on the black composition scale (indicating higher proportions of blacks in students' preadult environment), there are, on average, $56 \%$ higher odds of feeling close to other black students on campus $(P=.0802)$. This means that students who had more blacks in their neighborhoods and schools, and who had 


\section{American Journal of Sociology}

more black friends while in high school, had a higher probability of feeling close to other blacks upon attending college.

Model 2 replaces the black racial composition scale with one assessing the proportion of whites in respondents' neighborhoods, high schools, and friendship groups prior to attending college. We find that the odds of feeling close to black students in college is not significantly related to the proportion of whites in one's preadult environment $(P=.1880)$, although the relationship is in the expected direction. That our black racial composition variable significantly affected feelings of closeness while the white racial composition did not suggests that the relationship between closeness to other black students and interracial contact exists not because of the presence of whites, but because of the absence of blacks in their lives prior to attending college. For each of the relationships examined in the logistic regression models, we look to in-depth interviews and descriptive statistics to provide context and insight about the relationships uncovered above. $^{17}$

Racial and ethnic identification.-As reported in table 3, biracial students had significantly lower odds of closeness to other black students, even after controlling for SES and preadult integrative experiences. To better understand biracial students' social distance from other black students on campus, we decomposed our closeness scale into its four dimensions. From this, we learn that on every dimension of closeness, biracial students are more socially distant than their monoracial and ethnic-identified counterparts. A higher percentage of biracial students reported extreme or considerable alienation $(27 \%)$ from other black students on campus compared to monoracial $(18 \%)$ and ethnic-identified students (23\%). Whereas only $12 \%$ of monoracial students reported having poor experiences with other black students, $31 \%$ of ethnic-identified students and $40 \%$ of biracial students reported poor or negative experiences with other black students.

Differences also exist with respect to feeling part of the black community on campus. Sixty percent of biracial students reported that they feel very little or not at all a part of the black community on campus

\footnotetext{
${ }^{17}$ Including in model $1 \mathrm{a}$ variable indicating whether or not students were from Big City (Big City $=1$; Big City metropolitan area and beyond $=0$ ), we find a positive but insignificant effect of geographic location on odds of closeness $(P=.24)$. However, the inclusion of this variable, while having no substantive effect on being biracial or low SES, reduces to insignificance the effect of the black racial composition scale. This finding indicates that the effect of being from Big City may be reflecting extensive racial segregation of Big City relative to the outlying areas and beyond from which the other students were drawn. Whereas the average black racial composition scale from those residing in Big City is 4.88, suggesting that most of the neighbors, high school peers, and good friends during high school were black, that of students from areas outside of Big City was significantly lower $(3.38 ; P=.000)$.
} 


\section{Intraracial Diversity}

compared to $26 \%$ of monoracial students and $39 \%$ of the ethnic-identified students. Finally, biracial students also reported the highest proportion of good friends on campus who were nonblack. Whereas $22 \%$ of monoracial students and $39 \%$ of the ethnic-identified students reported that most or all of their good friends on campus were not black, $60 \%$ of biracial students reported that the majority of their friends were nonblack. Moreover, while $54 \%$ of monoracial students and $30 \%$ of the ethnic-identified students reported that all or most of their good friends on campus are black, no biracial student reported that all or most of their good friends on campus are black. To sum, a higher percentage of biracial students reported feeling alienation from and having poor experiences with other black students, and a lower percentage reported feeling a part of the black community on campus and having a majority of good friends on campus who are black.

An analysis of in-depth interviews identified factors that may explain biracials' higher likelihood of social distance. Biracial students appeared to have two issues with respect to their racial identities that created distance between themselves and other black students. First, consistent with the literature in this area, they expressed a need to embrace all aspects of their identities. It was just as important for these students to identify and express their white or Latino heritage, for instance, as it was to identify with the black part of their identity. However, they often expressed concern that others did not understand or respect this need, and they intimated that their own unwillingness to identify solely as black has created some tension in their relationships with other blacks. When asked to describe himself, Stephan, a sophomore, responded as follows:

I guess I'd describe myself first by culture, which would be Cuban and Bahamian, because my father was born in the Bahamas and my mother is full Cuban. When people ask me, I always feel uncomfortable just saying just black because I think there's more to it than that.

Two of the biracials we interviewed indicated that their nonblack parent encouraged them to identify with both aspects of their racial identity instead of solely accepting and embracing themselves as black. For instance, to explain the process of his racial identity formation, Stephan later states:

[My first name] is African, West-African meaning warrior, and [my middle name] is my mom's maiden name, which is Cuban, and she said it's because she never wants me to forget that side because she knows when I go outside, I won't be seen as Cuban, I'll just be seen as black, probably. But I always try to enforce that I'm more than just something you can define in one word. And I guess it's important to me to not let other people define me. 


\section{American Journal of Sociology}

Because defining is limiting. It creates boundaries you can't go outside of, and I think it's important not to have boundaries. It would be like limiting yourself.

Another biracial student, Mia, suggested something similar. She explained:

To say I'm black, my mother would just get upset. She says, "Mia, you are Hispanic, too." But I think there's a lot of things that are rooted in me that are rooted in most black people that aren't rooted in other people. But then I have to say, well, I am Hispanic, and I've grown up with a lot of Hispanic ideas, and my mother raised me, so then I have that aspect of my life. But, and other people always are asking me, "Well, Mia, what are you?" And when you say "I don't know," a lot of black people will feel, "Well look, if you don't know who you are, then you aren't us, because we know who we are, and we don't need that uncertainty with us."

From Stephan's and Mia's discussions, two points are clear. It is important for both that they not be defined solely by their black ancestry because their nonblack identities are integral to the way they define themselves and their culture. What is also clear is that for each, a parent appears to have played an important role in instilling within them the importance of their nonblack heritage. Intimated by Mia is the effect her racial ambiguity has on her relationships with other blacks. She suggests that her inability to define herself solely as black signifies that other blacks will not accept her as an individual of biracial and bicultural heritage.

Also creating social distance was the feeling held by biracial students that they were socially and culturally different from the other black students on campus. In essence, they did not "fit" into the black community on campus. The biracial students we interviewed believed they differed from other black students in terms of their norms, values, attitudes, issues, and interests that were important to them, as well as the level of interdependence they had with other black students and the black community on campus. From their often-limited interactions with other black students, they came to see themselves as outsiders. On one level, they viewed themselves differently from other blacks in "superficial" ways. They looked and dressed differently, listened to different music, and had different interests. One biracial student, Abigail, explained her social distance from blacks:

I don't have the same interests as they do. I don't listen to the same type of music. Personality-wise and physically, how I dress, the superficial things which I guess don't matter, but in a way it does because that's how everyone is, really. That's what they look at: what music do you listen to, what sports 
do you like, just so they can find similarities. And there's many differences between myself and many African-American people that I've met.

However, it was a deeper level of difference, in terms of values, attitudes, and issues important to them, that appeared to cause the greatest distance between biracials and other black students. The biracial students we interviewed found that they often disagreed with other blacks about issues that were vital to fitting in with the black community on campus, such as interracial dating. Whereas they perceived the black community on campus as having negative attitudes toward interracial relationships, they generally did not feel this way. Whereas $14 \%$ of monoracial students disapproved of interracial friendships and $23 \%$ disapproved of interracial dating, no biracial student reported disapproval of either.

Although the effect of ethnic identification was not significant in our analysis, the direction of the relationship was as anticipated: the ethnicidentified students had lower odds of closeness than monoracial students. ${ }^{18}$ In-depth interviews with ethnic-identified students suggest that nationality was their most salient feature and that it was primary over race in their self-identification. For those we spoke with, being in a country of Americans made nationality a greater identifying marker than race. Moreover, many of the ethnic-identified students expressed the view that as immigrants or offspring of immigrants, they were raised with a different culture and customs than native-born blacks. However, unlike previous studies in this area that have found great tension and conflict between foreign- and native-born blacks, we found no evidence of intraracial tensions or conflicts between first- and second-generation immigrants and their native-born counterparts.

Socioeconomic status and background.-Earlier we suggested a positive relationship between socioeconomic background and feelings of closeness. We hypothesized that given the increase in the number and proportion of middle- and upper-middle-class black students on college campuses, low-income students may perceive themselves as being qualitatively different from the "average" black student in terms of having fewer economic advantages and dissimilar values and experiences. Indeed, our data support this hypothesis. As explained above, relative to high SES students, low SES students had $88 \%$ lower odds of feeling close to other black students.

To better understand low SES students' social distance from other black

${ }^{18}$ Our data are limited in their ability to examine the extent to which the ethnicidentified participate in alternative ethnic communities, either in the university or the surrounding city. Such participation could affect an individual's feelings of closeness to black students. Indeed, of the five ethnic-identified students interviewed in-depth, two remarked on the importance of alternative ethnic communities in their lives. 


\section{American Journal of Sociology}

students on campus, we decomposed our closeness scale into its four dimensions, as done to examine differences in social distance by racial and ethnic identification. However, the findings from this "decomposition" differed from those of biracials and ethnics. Whereas biracials and to a lesser extent ethnic black students reported distance on each dimension of closeness, low SES students exhibited the greatest distance on only two dimensions of closeness: their experiences with other black students and the extent to which they felt part of the black community on campus. Whereas $43 \%$ of low SES students reported having poor experiences with other black students, only $18 \%$ of middle SES and $7 \%$ of high SES students reported the same. In addition, half of low SES students reported feeling very little or not at all a part of the black community on campus compared to one-third of middle SES and one-fifth of high SES students. However, their levels of alienation from other black students did not differ significantly from those of middle and high SES students, and a higher percentage of low SES students reported that all of their good friends on campus are black (21\% compared to $5 \%$ of middle SES students and no high SES students). These findings suggest that while low SES black students are not socially distant from blacks generally, as indicated by their black friendship networks, they feel considerably more social distance from the community of blacks on this campus.

Evidence from qualitative interviews is consistent with this hypothesis. Tamara, a young woman from a low-income background and raised on Chicago's South Side, is a case in point. Embedded in an all-black friendship network and reporting little alienation and isolation from other black students, Tamara also reported that she did not feel a part of the black community on campus. Though not asked about any class divisions or tensions on campus, it became clear by her responses to a variety of questions that Tamara felt resentment toward her higher SES black counterparts that stemmed from two impressions she had of other black students. One impression was that of hypocrisy by black middle- and upperclass students. She complained that while her more affluent counterparts often mocked those who were raised in the ghetto, they often tried to act "ghetto" themselves. She explained:

They just try to make it seem like they're ghetto. That's what they term us who don't have any money. And they make it seem as if it's negative but they want to pretend to be it.

When asked in what ways they try to act ghetto, Tamara referred to their speech and style of dress: 


\section{Intraracial Diversity}

A tendency to curse. I mean we all curse, but I guess for some it comes more natural if that's what you've heard, and when they do it, it sounds funny, and it sounds like they're trying to mimic me or any of the others of us who don't have any money here. And style of dress. It's just a lot.

Tamara also felt resentful because she had to work two jobs to put herself through school while other blacks on campus appeared to have money to spend more freely without work. When asked if and why she felt that most students at the university had values and attitudes different from her own, Tamara replied the following way speaking specifically about black students, even though the question referred to the general university student:

It's like money is not important to them, but I mean, many of the black students here don't work. A lot of them, I don't think they work. And I have to work two jobs, or I wouldn't be here. It's like money is nothing. They can go spend two, three hundred dollars on a jacket and I would kill for a couple of dollars.

Tamara's perception of class divisions suggests why low SES students feel socially distant from other black students. Given that $87 \%$ of black students of Big City University are from middle- and upper-middle-class backgrounds, low SES students are a minority. Their past and present experiences are not shared by the majority of black students on campus. Therefore, they may perceive themselves quite differently from their more advantaged peers, and thus may be more likely to report feelings of social distance from other black students and the black community on campus. In addition, the distance reported by low SES students from their black classmates may also stem in part from their belief that their more advantaged counterparts express themselves in ways inconsistent with their middle-class experiences. Thus, they view attempts to "act black" (i.e., inner city and poor) as hypocritical and offensive given their own struggles for upward mobility.

The social distance reported by low SES students appears specific to their higher SES counterparts as opposed to blacks as a collective group. This is worth noting, given that the social distance reported by biracials, and to a lesser extent ethnic-identified students, appeared to be driven by their social distance from the larger black community. Whereas biracials reported greater feelings of alienation, poorer experiences, less connection to the black community on campus, and significantly fewer black friends on campus, low SES black students generally had more black friends than did their higher SES counterparts and did not report greater feelings of alienation. Their distance from black students stemmed primarily from their disappointing experiences with other black students and 


\section{American Journal of Sociology}

from not feeling a part of the black community on campus. Thus, the social distance expressed among biracial students appears to be qualitatively different from the social distance expressed by low SES students.

Preadult integrative experiences.-As indicated by the results of the logistic regression analysis, as the proportion of blacks in students' preadult environments increases, the odds of feeling close to other black students also increases. This finding is consistent with previous work. Researchers in this area have proposed that the relationship between closeness and interracial contact exists either because of increased contact with whites and members of other groups or because of decreased contact with blacks, each resulting in declining feelings of closeness. Our analyses revealed that although the increased presence of whites in their neighborhoods, schools, and friendship networks decreased the odds of feeling close, it was the presence of blacks that significantly affected the odds of feeling close to other black students. As Dawson contends (1994), racial group identification is in large part a function of the extent to which individuals have access to information relevant to that identity and believe that a particular identity is consistent with their own reality. Racial identification becomes less important when information about the political, economic, and social worlds of blacks is less accessible. Our in-depth interviews provide context for this discussion.

For those students raised in predominantly black environments, knowledge about the political, economic, and social worlds of blacks was a given. Attending predominantly black schools, living in predominantly black neighborhoods, and embeddedness in predominantly black social networks gave them automatic insight into the issues and interests important to blacks as a collective. Some students discussed how being raised in predominantly black backgrounds provided them with a wealth of information about the historical treatment of blacks in this country and how this treatment has shaped who blacks are as a people. As Nathan, a close-feeling student explained:

My high school was kind of different from other people's high schools. I mean, black history month was a big thing in my high school. We had a teacher named Ms. Colton who would teach history. She would teach history maybe one day out of the week. We talking about "his"tory. Most of the time she would talk about either slavery, she would talk about the Civil Rights movement, and I don't think she did a lot of reading on it herself, but she would just talk about all the problems she had coming up. Because she was from Chicago, she would talk about all of the racial problems that was in Chicago. She would talk about how white people did this to black people. I got that from a lot of people in my high school. At home, my parents, they would tell me stories about racist things white people would do. They would tell me in Gary, 20 years ago, they would tell me that if you was a black person in Gary walking out in the street after six o'clock, 
they could shoot you, and I heard stories like that. So I was always getting that all throughout my life. And I don't know if I exactly grew up as a racist, but I was definitely racially aware.

Nathan's experience differed significantly from that of many students raised in predominantly white environments. Of the students who attended predominantly white high schools, resided in predominantly white neighborhoods, and were embedded in predominantly white friendship networks, we interviewed many who expressed ignorance about the political, economic, and social worlds of blacks generally and who doubted their ability to relate socially and culturally to other black students. Throughout their preadult experiences, they received little, if any, information about the issues and interests important to the black collective, and this lack of knowledge placed them at a disadvantage in their interactions with other black students. Indeed, some expressed great ambivalence about what to say to other black students as well as how to behave to gain acceptance from the black community on campus.

Lissette, a socially distant black student, represents a prime example. Raised in a predominantly white community, attending predominantly white schools, and having predominantly white friendship networks, Lisette recognized as an adolescent that the way in which her life was structured created substantial social distance from other blacks. During the interview, she expressed a great desire to be a part of the black community on campus. However, she was constantly frustrated by her inability to do so, an inability that stemmed in part from her physical distance from black communities while growing up and her lack of knowledge about what to say and do once she had access to such communities. Indeed, she blamed her inability to connect with other blacks on her father, who, in an effort to provide his family with the best opportunities, located his family in predominantly white surroundings:

\footnotetext{
He didn't realize that that's how I felt for so long, that I felt so lost sometimes. And at times I would get angry at him [but] I wouldn't tell him, "Dad, do you realize that by putting us in Catholic school, that there aren't any black students for us to be with and the few who do go to the same schools, they live with black people and we don't." And [blacks] don't realize that just because we don't live with them [doesn't mean] we don't have problems, or just because we don't live with them doesn't mean that I don't know how to dance. It was hard for me to come to him and tell him that because he was working so hard to ensure that we got a good education and we were living in a good neighborhood.
}

In Lissette's eyes, her lack of exposure to other blacks and the black community made her feel like an outsider and led to her perception that 
American Journal of Sociology

she was also viewed as an outsider by other blacks. She recounts her attempts to fit in:

It's kind of like I was pulling out of a hat anything that I thought would make me more black . . . but it wasn't enough. It was never enough, cause I was always gonna be, whenever my mouth opened, it would be a little bit different [than] what they sounded like.

Unlike Nathan, whose "racial awareness" was established by his embeddedness in predominantly black environments, Lissette's preadult experiences did not provide her with the racial awareness to navigate comfortably within the black community on campus, thus heightening her self-perception as an outsider and reinforcing her feelings of social distance from other black students.

Interviews also revealed that those from predominantly white environments were socially distant because they perceived themselves as socially and culturally different from the other black students on campus. They believed that their interests differed from those of other black students and that the issues important to the black community on campus were not issues that were important to them. The issues and interests of those raised in predominantly black environments, and to a lesser extent racially integrated environments, often centered on race or on being black. On the whole, those from predominantly black environments enjoyed listening to music by $\mathrm{R} \& \mathrm{~B}$, rap, and/or hip hop artists, and they strongly supported movies with black actors, by black writers, directors, and producers, or about the black experience, for instance. In contrast, the issues and interests of many students raised in predominantly white environments were in large part shaped by the community of whites from which they came; being black was not a central theme around which they defined their existence. The interests of these students mirrored those of the communities in which they were embedded, and the issues that were important to them more closely resembled those of their white or nonblack counterparts. In sum, because the preadult experiences of students from predominantly white environments were generally absent of racial interpretations or excluded black points of view, students from such communities were generally not made "racially aware" and felt uncomfortable with the racialized issues and interests relevant to the black community on campus.

However, it is not the case that predominantly white preadult experiences automatically resulted in social distance from other blacks. Through in-depth interviews we discovered that for other students raised in predominantly white environments, consistent and positive information about the happenings within the larger black community helped to con- 


\section{Intraracial Diversity}

nect them to the black community and allowed them to identify with other blacks even though they had not been raised among blacks. Although physically distant from other blacks, they achieved racial awareness by maintaining ties with different aspects of the black community. Meredith, a very close-feeling black student who was raised in a predominantly white neighborhood and who attended predominantly white schools reported that although she grew up in predominantly white environments, her parents maintained links to the larger black community and consistently provided her with information relevant to the black experience. Meredith explained:

My dad would always have us read articles about black people, newspapers out loud to him, whatever, and [copy] stuff for us to make sure that we've read it. I also remember growing up, I played the piano, and so the music school that I went to was black. It was a black, Christian music school. I also had obvious African-American mentors in my life; I had two music teachers during the time I was playing piano. They were both AfricanAmerican women, very strong in their belief system, and they served as really powerful mentors for me. So I also had that type of exposure. I was constantly reminded, "You're black. You need to be proud of the fact that you're black." So I mean, I think it comes to that level of whether or not it's incorporated into the fabric of your family and your self-image.

Although Meredith spent a great deal of her youth in all-white communities, she described how her family members went out of their way to provide her with access to and knowledge about issues important to the black community. They also exposed her to black mentors who could help provide her with a sense of what it means to be black and part of the black community. As a result, although most of her social interaction took place in white communities, her parents' active stance allowed her to forge and maintain primary relationships with black figures; therefore, she learned and appreciated the social norms, values, and interests of the larger black community. Moreover, like Nathan, Meredith received frequent messages from her parents about historical treatment of blacks in this country and how this treatment has shaped who blacks are as a people today. Explaining her parent's idea of what it means to be black, Meredith stated:

For [my parents] that meant "you are black, so you need to know about your history. You are black, so you need to read such and such a book that will tell you such and such about black history. You are black, so you need to incorporate such and such idea into your makeup so you can succeed." Those were the types of messages that I got growing up. 


\section{American Journal of Sociology}

Thus, despite having been raised in predominantly white environments, Meredith was inculcated with the racial awareness necessary to connect to and identify with other blacks generally, and, at this period in her life, the black community on campus in particular. Her access to and knowledge about black experiences combined with frequent, positive messages from her parents about what it means to be black meant that, unlike Lissette, Meredith did not feel like an outsider. Instead, knowing the issues and interests important to the larger black community, Meredith was able to relate to the other black students and navigate comfortably within the black community on campus.

\section{SUMMARY AND DISCUSSION}

Employing as a case study black college students who attend a predominantly white university, we find that, although black students continue to create their own social groups to combat feelings of isolation and alienation from the larger campus community, there exists considerable variation in the level of closeness they feel toward other black students and the black community on campus. One-third of the black students at Big City University had few or no black friends as a proportion of their good friends on campus and did not feel part of the black campus community. One-fifth felt extremely or considerably alienated from other black students and were categorized as socially distant. Socially distant students were less likely to rely on other black students for need satisfaction and social interaction, as evidenced by their lack of participation in blackspecified groups such as the BSO, or in such informal activities as eating with black students at the Black Table in the dining hall. Differential feelings of closeness were also reflected in students' attitudes about issues considered important to the black community, such as interracial dating and friendships, with socially distant students showing approval of and greater involvement in interracial relationships compared to the larger black student body. These findings suggest that homogeneity in values, attitudes, and experiences among black students should not be assumed.

Based on in-depth interviews, our study suggests that what is driving students' feelings of closeness to or distance from other black students is the extent to which they perceive themselves to be different from the majority of other black students on campus. These perceived differences stem from three factors: racial/ethnic identification, SES, and preadult integrative experiences. First, biracial students are significantly less likely to feel close to other black students on campus. We determined through in-depth interviews that their social distance is in part a function of their need to embrace both the nonblack and black aspects of their racial identity, a choice that they feel creates tension between themselves and 
monoracial blacks. The other aspect of their social distance is rooted in their perception that they differ socially and culturally from other blacks so much so that they are unable to relate to other blacks as a group and fit into the black community on campus.

Second, low SES students are less likely to feel close to black students on campus when compared to high SES students. Because the majority of black students attending Big City University are from middle- and upper-middle-class families, low-income students tend to perceive themselves as socially and economically different from their peers, creating significant distance between themselves and the general black student body.

Third, consistent with previous research, we find that preadult interracial contact has a negative effect on closeness to other blacks. This relationship is primarily a function of maintaining consistent and positive relationships with the larger black community and receiving frequent messages about what it means to be black in America prior to attending college. For students embedded in predominantly black environments, consistent and positive relationships and frequent messages were a given. For those raised in predominantly white environments, consistent relationships and frequent messages were not the norm. However, students whose parents made efforts to inform their children about the happenings in the black community, who linked their children to other blacks, and who provided frequent and positive messages about what it means to be black much improved the chances that their children would connect and identify with other blacks and the larger black community upon attending college.

The fairly unusual context of this study limits our ability to generalize results to all blacks. The findings reported here are interpreted only in reference to this and similar undergraduate populations. However, the findings of this study advance the literature both methodologically and theoretically. In previous research closeness has been limited to a measure of blacks' affective response to all blacks. Although our measure in no way represents an exhaustive one, it extends prior measures not only by capturing affect, but also by capturing the level and quality of interactions within the community of blacks in which individuals are embedded. Thus, it represents a more multidimensional concept, one that allows links to be made between abstract feeling and concrete interactions.

Given this multidimensional approach and the resulting findings, a reconceptualization of the meaning of "closeness" is required. This is primarily because the data elucidate several contingencies that shape or influence closeness, factors that have not been thoroughly considered in previous work. These contingencies include, but are not limited to, context, representation, and socialization. 
American Journal of Sociology

First, context matters. Our research suggests that closeness is contingent on the reference group in question such that when placed in various settings with different types of people, one's responses to questions of closeness will vary systematically. Thus, whereas previous research has found that those of low SES are more likely to feel close to other blacks, we find that within the context of a predominantly affluent black population, those of low SES backgrounds are less likely to feel close.

Second, representation is implicated in this measure of closeness and raises questions about why people choose to signify their closeness in specific ways. Recall Tamara's resentment toward her classmates of middle and high SES status: "They just try to make it seem like they're ghetto. And they make it seem as if it's negative but they want to pretend to be it." Basically, Tamara was pointing to a pattern she observed among the black middle class and that was expressed by some of the middleclass blacks themselves. The common ethos that black equals black, low income, ghetto, and hip hop had been usurped by the middle-class blacks, many of whom had not shared the experiences of their more disadvantaged counterparts, but who had taken on these identities as their own under the mantra of "keeping it real." More important, however, was how they used these expressions of blackness in an effort to feel close to other blacks and to feel connected to the larger black community; in essence, an expression of symbolic ethnicity among the black middle class. Closeness, then, may be contingent on whether one chooses to represent oneself in ways consistent with the common ethos of a particular reference group.

Third, parental socialization influences the extent to which individuals feel close to other blacks and the larger black community. The findings reported here suggest that while most of the black students raised in predominantly white communities expressed distance from their black peers, some did not. These exceptions had received frequent and positive messages from their parents about the social, political, and economic worlds of blacks, and generally went out of their way to maintain some type of connection. Meredith, for example, who was raised in predominantly white neighborhoods and attended predominantly white schools and who reported the lack of any African-Americans in her preadult friendship networks, was supplied by her parents with books and articles relevant to the black experience, and she was encouraged to participate in some black cultural activities. These provided the bridge she needed to maintain a social and cultural connection and to feel close to the larger black community given the absence of direct, sustained contact. Thus, for those raised in predominantly white environments, closeness was contingent on the socialization messages provided by parents during important stages of identity development.

Although this study is bound to a particular time, population, and 


\section{Intraracial Diversity}

setting, it has applicability to other times, people, and spaces. Through this reconceptualization of closeness, we have the potential to investigate whether the contingencies outlined above matter for different groups, such as those of other races and ethnicities, whether they play out differently for other groups, or whether there are additional contingencies yet to be considered. As a conceptual scheme, then, the idea of closeness has not been fully developed in this area and thus is ripe for future research.

\section{REFERENCES}

Allen, Richard L., Michael C. Dawson, and Ronald E. Brown. 1989. "A Schema-Based Approach to Modeling an African-American Racial Belief System.” American Political Science Review 83 (2): 421-41.

Allen, Walter R. 1992. "The Color of Success: African-American College Student Outcomes at Predominantly White and Historically Black Public Colleges and Universities." Harvard Educational Review 62 (1): 26-44.

Bowen, William G., and Derek Bok. 1998. The Shape of the River: Long-term Consequences of Considering Race in College and University Admissions. Princeton, N.J.: Princeton University Press.

Bowles, Dorcas D. 1993. "Bi-Racial Identity: Children Born to African-American and White Couples." Clinical Social Work Journal 21 (4): 417-28.

Broman, Clifford L., Harold Neighbors, and James S. Jackson. 1988. "Racial Group Identification among Black Adults." Social Forces 67 (1): 146-58.

Brown, Philip M. 1990. "Biracial Identity and Social Marginality." Child and Adolescent Social Work 7 (4): 319-37.

Collins, Patricia Hill. 1990. Black Feminist Thought: Knowledge, Consciousness, and the Politics of Empowerment. Boston: Unwin Hyman.

Daniel, G. Reginald. 1996. "Black and White Identity in the New Millenium." Pp. 121-39 in The Multiracial Experience: Racial Borders as the New Frontier, edited by Maria P. P. Root. Thousand Oaks, Calif.: Sage.

Dawson, Michael C. 1994. Behind the Mule: Race and Class in African-American Politics. Princeton, N.J.: Princeton University Press.

Demo, David H., and Michael Hughes. 1991. "Socialization and Racial Identity among Black Americans." Social Psychology Quarterly 53 (4): 364-74.

Denton, Nancy, and Douglas Massey. 1989. "Racial Identity among Caribbean Hispanics: The Effect of Double Minority Status on Residential Segregation." American Sociological Review 54 (5): 790-808.

Farley, Reynolds. 1996. "Black-White Residential Segregation: The Views of Myrdal in the 1940s and Trends of the 1980s." Pp. 45-75 in An American Dilemma Revisited: Race Relations in a Changing World, edited by Obie Clayton, Jr. New York: Russell Sage Foundation.

Farley, Reynolds, and Walter R. Allen. 1987. The Color Line and the Quality of Life in America. New York: Russell Sage Foundation.

Farley, Reynolds, and William H. Frey. 1994. "Changes in the Segregation of Whites from Blacks during the 1980s: Small Steps toward a More Integrated Society." American Sociological Review 59:23-45

Frey, William H., and Reynolds Farley. 1996. "Latino, Asian, and Black Segregation in U. S. Metropolitan Areas: Are Multiethnic Metros Different?" Demography 33 (1): $35-50$.

Gibbs, Jewelle Taylor. 1998. "Biracial Adolescents." Pp. 305-32 in Children of Color: Psychological Interventions with Culturally Diverse Youth, edited by Jewelle Taylor Gibbs. San Francisco: Jossey-Bass. 


\section{American Journal of Sociology}

Hall, Marcia L., and Walter Allen 1989. "Race Consciousness among African American College Students." Pp. 172-97 in Black Students: Psychosocial Issues and Academic Achievement, edited by G. L. Berry and J. K. Asamen. Newbury Park, Calif.: Sage Publications.

Harris, David. 1995. "Exploring the Determinants of Adult Black Identity: Context and Process." Social Forces 74 (1): 227-41.

Jaynes, Gerald David, and Robin M. Williams, Jr., eds. 1989. A Common Destiny: Blacks and American Society. Washington, D.C.: National Academy Press.

Kasinitz, Paul. 1992. Caribbean New York: Black Immigrants and the Politics of Race. Ithaca, N.Y.: Cornell University Press.

Laumann, Edward O. 1973. Bonds of Pluralism. New York: Wiley.

Marsden, Peter V., and Karen E. Campbell. 1984. "Measuring Tie Strength." Social Forces 63 (2): 482-501.

Massey, Douglas S., and Nancy A. Denton. 1988. "Suburbanization and Segregation in U.S. Metropolitan Areas." American Journal of Sociology 94 (3): 592-626.

Mathews, Linda. "More than Identity Rides on a New Racial Category." New York Times, Saturday, July 6, 1996, p. A-1.

Newman, Katherine S. 1999. No Shame in My Game: The Working Poor in the Inner City. New York: Knopf and Russell Sage Foundation.

Njeri, Itabari. "A Sense of Identity.” Los Angeles Times, June 5, 1988, p. C-1

Outtz, Janice Hamilton. 1994. Shattering Stereotypes: A Demographic Look at Children in the United States. Center for Demographic Policy, Institute for Educational Leadership.

Overmier, Kathi. 1990. "Biracial Adolescents: Areas of Conflict in Identity Formation." Journal of Applied Social Sciences 14 (2): 157-76.

Porterfield, Ernest. 1978. Black and White Mixed Marriages. Chicago: Nelson-Hall.

Root, Maria P. P., ed. 1992. Racially Mixed People in America. Newbury Park, Calif.: Sage Publications.

1996. "The Multiracial Experience: Racial Borders as a Significant Frontier in Race Relations." Pp. xiii-xxviii in The Multiracial Experience: Racial Borders as the New Frontier, edited by Maria P. P. Root. Thousand Oaks, Calif.: Sage Publications.

Rosenblatt, Paul C., Terri A. Karis, and Richard D. Powell. 1995. Multiracial Couples: Black and White Voices. Thousand Oaks, Calif.: Sage Publications.

St. Jean, Yanick, and Robert E. Parker. 1995. "Disapproval of Interracial Unions: The Case of Black Females." Pp. 341-51 in American Families: Issues in Race and Ethnicity, edited by Cardell K. Jacobson. New York: Garland.

Sebring, Deborah L. 1985. "Considerations in Counseling Interracial Children.” Journal of Non-White Concerns in Personnel and Guidance 13:3-9.

Sigelman, Lee, Timothy Bledsoe, Susan Welch, and Michael W. Combs. 1996. "Making Contact? Black-White Social Interaction in an Urban Setting." American Journal of Sociology 101 (5): 1306-32.

Simpson, Andrea. 1998. The Tie That Binds: Identity and Political Attitudes in the Post-Civil Rights Generation. New York: New York University Press.

Smith, James P., and Finis R. Welch. 1989. "Black Economic Progress after Myrdal." Journal of Economic Literature 27:519-64.

Spencer, Jon Michael. 1997. The New Colored People: The Mixed-Race Movement in America. New York: New York University Press.

Spickard, Paul R. 1989. Mixed Blood: Intermarriage and Ethnic Identity in TwentiethCentury America. Madison: University of Wisconsin Press.

Sutton, Constance R., and Susan R. Makiesky-Barrow. 1987. "Migration and West Indian Racial and Ethnic Consciousness." Pp. 92-117 in Caribbean Life in New York: Sociocultural Dimensions, edited by Constance R. Sutton and Elisa M. Chaney. New York: Center for Migration Studies of New York. 


\section{Intraracial Diversity}

Tatum, Beverly Daniel. 1987. Assimilation Blues: Black Families in a White Community. New York: Greenwood Press.

Thornton, Michael C. 1996. "Hidden Agendas, Identity Theories, and Multiracial People." Pp. 101-19 in The Multiracial Experience: Racial Borders as the New Frontier, edited by Maria P. P. Root. Thousand Oaks, Calif.: Sage.

Thornton, Michael C., Linda M. Chatters, Robert Joseph Taylor, and Walter R. Allen. 1990. "Sociodemographic and Environmental Correlates of Racial Socialization by Black Parents." Child Development 61 (2): 401-9.

Thornton, Michael C., Thanh V. Tran, and Robert Joseph Taylor. 1997. "Multiple Dimensions of Racial Group Identification among Adult Black Americans." Journal of Black Psychology 23 (3): 293-309.

U.S. Bureau of the Census. 1993. Statistical Abstract of the United States, 1993. Washington, D.C.: Government Printing Office.

. 1996. "Native and Foreign-Born Populations, by Selected Characteristics: 1996." No. 55. in Statistical Abstracts of the U.S.: 1996 Population Characteristics. Available From Statistical Universe (Online Service). Bethesda, Md.: Congressional Information Service.

Waters, Mary C. 1996. "Ethnic and Racial Identity of Second-Generation Black Immigrants in New York City." Pp. 171-96 in The New Second Generation, edited by Alejandro Portes. New York: Russell Sage Foundation.

1999. Black Identities: West Indian Immigrant Dreams and American Realities. Cambridge, Mass.: Harvard University Press.

Wilson, William Julius. 1978. The Declining Significance of Race: Blacks and Changing American Institutions. Chicago: University of Chicago Press.

Woldemikael, Tekle Mariam. 1989. Becoming Black American: Haitians and American Institutions in Evanston, Illinois. New York: AMS Press. 